agriTECH, 41 (1) 2021, 85-94

\title{
Bio-fertilizer Impact on Production Efficiency and Yield of Corn (Zea mays) Cultivars Under Water Deficiency
}

\author{
Elnaz Farajzadeh-Memari-Tabrizi'*, Marzieh Babashpour-As|² \\ ${ }^{1}$ Department of Agronomy, Malekan Branch, Islamic Azad University, Malekan, Iran \\ ${ }^{2}$ Department of Horticultural Science, Maragheh Branch, Islamic Azad University, Maragheh, Iran \\ *Corresponding author: Elnaz Farajzadeh-Memari-Tabrizi; Email: farajzadeh_elnaz@yahoo.com
}

Submission: August 12, 2020; Revision: September 11, 2020; September 21, 2020;

Acceptance: September 25, 2020

\begin{abstract}
The application of bio-fertilizer (Glomus mosseae) and the selection of suitable cultivars are simple solutions to mitigate stress conditions such as water deficiency. This study was conducted in 2016 as a split-plot that was based on randomized complete block design with 3 replications. The effects of irrigation level, bio-fertilizer application and cultivar type on the reproductive efficiency and yield of corn were compared in the field experiment. Irrigation levels (after 70,110 and $150 \mathrm{~mm}$ of pan evaporation) were placed as the main factor in the main plots. Application and non-application of bio-fertilizer (Glomus mosseae) as well as cultivar type (cultivars, 640 and 704) were placed in the subplots to study the physiological differences, reproductive efficiency, and yield of corn. This study showed that the cultivars performed differently in their response to water deficiency. The highest grain yield for 704 cultivars was obtained when we applied irrigation after $70 \mathrm{~mm}$ evaporation from pan. When subjected to the treatment of irrigation after 110 and $150 \mathrm{~mm}$ evaporation from pan, lower grain yield per unit area of $19 \%$ and $50.6 \%$, respectively was recorded. The 640 cultivars produced less yield under full irrigation than 704 cultivars. Water deficiency had no beneficial effects on grain yield per unit area $(P>0.01)$. It was also observed that biofertilizer treatment increased the corn yield by $25.2 \%$. Water deficiency, bio-fertilizer and cultivar type affected the grain yield as differences were observed in the main components of kernel row number and 100-kernel weight. Water deficiency had no beneficial effects on 'chlorophyll a' content, but decreased the content of chlorophyll b. Water deficiency and bio-fertilizer application caused an increase in the catalase and peroxidase content. The best plant performance was observed in plants grown under complete bio-fertilizer (704 cultivar) and at after $70 \mathrm{~mm}$ irrigation level. Bio-fertilizers can be used in order to improve corn production and also as environmentally friendly fertilizers under deficit irrigation regimes.
\end{abstract}

Keywords: Bio-fertilizers; corn; water deficiency; cultivar; yield

\section{INTRODUCTION}

In recent years, water scarcity has forced many farmers to employ various strategies and conduct many breeding programs to improve drought tolerance. Water deficiency is one of the significant causes of corn's weak performance, and this issue affects the majority of the farming regions around the world. Traditionally, water deficiency is a multi-dimensional stress that affects plants at different levels. Therefore, the physiological response to water deficiency is very complicated and unpredictable. A deficit irrigation system describes exposing crops to a certain level of drought stress by withholding irrigation and/or reducing the amount of irrigation water either during a particular period or throughout the growing season. This system has been successfully employed to maximize water use efficiency and achieve higher yields per unit of irrigation water in different crops (Jahanzad et al., 2013; Afshar et al., 2014). The main impact of water deficiency in corn is 
the delay in silk development resulting in an unbalance between pollination and silk development. This resulting unbalance is one of the important factors causing yield reduction (Maazou et al., 2016).

Corn production depends on climate, geographical conditions, irrigation levels, cultivar and application of bio-fertilizers. As a result of the increase in food demand, it is important to determine the effect of bio-fertilizers on quantity and quality of corn. This will help identify the best bio-fertilizers that can be used to increase corn production efficiency. Application of biochemical fertilizers at the beginning of the growing season may result in the conversion of some of its biochemical components to other forms that become unavailable for plants resulting in economic loss. In order to increase the efficiency of nutrients intake, fertilizers must be capable of providing essential nutrients for a long time. Application methods can also have significant effects on plants yield. Applying Mycorrhiza through some fertilizer may have more beneficial effects in comparison to applying it directly to the soil. The encouraging performance of natural and biological fertilizers in crop production and the fact that they have less ecological footprint compared with chemical fertilizers has influenced many studies (Dadrasan et al., 2015). Mycorrhizas are fungi that colonize the roots of crops. This symbiotic elationship is beneficial for both the fungi and the plants. Symbiotic fungi increase the nutrient absorption of host plants and can increase the growth and quality of host plant as well as its resistance to environmental stresses (Oskuie and Cirus, 2015). Studies have reported that bio-fertilizers increase proline, kernel yield, antioxidant activity and the production yield of corn (Chen et al., 2014; Nyaga et al., 2014).

In semi-arid regions, especially regions with limited water availability like Tabriz, in Iran, there is little information about the effect of irrigation, cultivar and fertilization on the growth and yield of corn. The aim of this study was to evaluate the effect of bio-fertilizer application on growth and yield of different cultivars of corn that are grown under different irrigation levels.

\section{Materials and Method}

This experiment was conducted in 2016 at the Agriculture station of Islamic Azad University, Malekan-
Iran in north-west Iran ( $\left.37^{\circ} 24^{\prime} \mathrm{N}, 46^{\circ} 17^{\prime} \mathrm{E} ; 1360 \mathrm{~m}\right)$. The split-plot design was used in this experiment, and it was based on completely randomized block design with 3 replications. The first factor, irrigation levels (after 70, 110 and $150 \mathrm{~mm}$ of evaporation from evaporation pan), was placed in the main plots. The second factor, biofertilizer treatments (no-application and application of bio-fertilizer), and the third factor, cultivars (640 and 704) were placed in the subplots. In early April 2016, when the soil was ready for sowing, superficial ploughing was done to control weeds after the soil was sampled. Land preparation and construction of ridge and furrow were done as well in accordance to land cultivation practices. First irrigation was performed on 29th April 2016. Corn seeds were gotten from Pakan Institute, Isfahan-Iran. On 4th May, 2016, the seeds were sown at depth of 4 $\mathrm{cm}$ as dry farming within a row distance of $15 \mathrm{~cm}$ on the ridges' water trail, and the distance between rows was $60 \mathrm{~cm}$. To ensure germination, two seeds were planted in each location. The first irrigation was carried out 2 days after sowing and further irrigations were applied subsequently at 5 days intervals. After planting and establishing of plants, thinning and weeding were carried out in the 2-4 leaf stage, weeding was continued until the end of vegetative growth.

For soil analysis, 6-point field samples were taken from depths of $0-30 \mathrm{~cm}$ and sent to the laboratory at pre-sowing stage. After analysis, the physical and chemical properties of soil were determined and are shown in Table 1.

\section{Nitrogen}

Sampling was conducted at the kernel filling stage, and $0.5 \mathrm{~m}$ of each plot was eliminated as marginal effect. At the flowering stage, the upper leaf of a competing plant was selected and separated from the mother plant before being transferred to the laboratory. First, a solution was prepared by mixing liquid glue and white alcohol. A brush is then used to apply a thin layer of the solution to the leaf's underside, and the prepared sample was then dried and transferred onto glass slides using adhesive tape to hold it on. While on each slide, a lens with a magnification of 40 was used to count 6 microscopic field of view by and the average was calculated (Abdallah et al., 2013; Šantrůček et al., 2014).

Table 1. Some of the physicochemical characteristics of the field soil

\begin{tabular}{|c|c|c|c|c|c|c|c|c|c|c|c|c|}
\hline $\begin{array}{c}\text { EC } \\
(\mathrm{ds} / \mathrm{m})\end{array}$ & $\mathrm{pH}$ & $\begin{array}{l}\text { Saturation } \\
(\%)\end{array}$ & TNV & $\begin{array}{l}\mathrm{OC} \\
(\%)\end{array}$ & $\begin{array}{l}\text { TN } \\
(\%)\end{array}$ & $\begin{array}{c}\text { Absorbable P } \\
(\%)\end{array}$ & $\begin{array}{c}\text { Absorbable K } \\
(\%)\end{array}$ & $\begin{array}{c}\mathrm{Zn} \\
(\mathrm{Mg} / \mathrm{kg})\end{array}$ & $\begin{array}{l}\text { Sand } \\
(\%)\end{array}$ & $\begin{array}{l}\text { Silt } \\
(\%)\end{array}$ & $\begin{array}{l}\text { Clay } \\
(\%)\end{array}$ & $\begin{array}{l}\text { Soil } \\
\text { texture }\end{array}$ \\
\hline 1.42 & 7 & 47 & & 1.29 & 0 & & & & 37 & 50 & 13 & $\begin{array}{l}\text { Silt } \\
\text { loam }\end{array}$ \\
\hline
\end{tabular}

EC: Electrical conductivity; TNV: Total Neutralizing Value; OC: Organic Carbon; TN: Total Nitrogen. 
The final harvest was carried out from an area equivalent to one square meter from the second row of each plot. The kernels were then separated from the corn plant and the kernel weight of the kernels harvested from one square meter was determined. To measure chlorophyll content of leaves at the end of flowering, samples were taken from terminal leaves of competing plants and transferred to the laboratory, $1.0 \mathrm{~g}$ of plant tissue was pulverized in a porcelain mortar with liquid nitrogen, and $10 \mathrm{~mL}$ of $80 \%$ acetone was added, it was then centrifuged for 10 minutes at a speed of 6,000 rpm and a high solution absorbance at the wavelengths of 663,645 and $470 \mathrm{~nm}$, respectively, was set on the spectrophotometer for the measurement of chlorophyll a, chlorophyll b and carotenoid content. Subsequently, chlorophyll a, chlorophyll b, and sample carotenoid content were obtained using the Equation 1 and 2.

$$
\begin{aligned}
& \text { Chlorophyll } \mathrm{a}=\frac{\left(19.3 \times A_{663}-0.86 \times A_{645}\right) / \mathrm{V}}{100 \mathrm{~W}} \\
& \text { Chlorophyll } \mathrm{b}=\frac{\left(19.3 \times A_{645}-3.6 \times A_{663}\right) / \mathrm{V}}{100 \mathrm{~W}}
\end{aligned}
$$

$\mathrm{V}$ is the volume of the centrifuged solution, $\mathrm{A}$ is light absorption at mentioned wavelengths, and $\mathrm{W}$ is the weight of the fresh sample in grams (Khalil and ElNoemani, 2015).

\section{Measurement of Malondialdehyde}

The gas chromatographic HPLC technique was employed to determine the amount of malondialdehyde (MDA). The extract used for the measurement of H-dG08 was transferred to an octadecyl silica-gel column based on thiobarbituric acid method with 12 moles of MDA chloroacetic acid. After reaching equilibrium, the column was washed with the mobile phase consisting of a methanol-phosphate buffer. A visible spectrophotometer at a wavelength of 532 was used to detect the MDA peak, and the measurement was based on the area under the curve peak. As a standard, pure MDA with different ratios was drawn in wash buffer and used to prepare the standard curve (Mirzaei et al., 2011).

\section{Measuring Proline Content}

Leaf samples were taken at the flowering stage and were crushed using an electric mill to obtain the green extract. The transparent and clear part of the extract was transferred into a test tube. This operation was repeated multiple times. The extract taken from all treatments were centrifuged at $3500 \mathrm{rpm}$ for $10 \mathrm{~min}$ at $10^{\circ} \mathrm{C}$. The top centrifuged pure green extract was separated and kept in test tubes with stoppers at 4 ${ }^{\circ} \mathrm{C}$ to determine the free proline content. $1 \mathrm{~mL}$ of the separated extract was mixed with $10 \mathrm{~mL}$ of doubleddistilled water and then stirred using a shaker. $5 \mathrm{~mL}$ of ninhydrin reagent was added to the sample. To prepare the ninhydrin reagent, $0.125 \mathrm{~g}$ of ninhydrin, $2 \mathrm{~mL}$ of 6 $\mathrm{M}$ phosphoric acid and $3 \mathrm{~mL}$ of glacial acetic acid were mixed. In order to fully dissolve ninhydrin in phosphoric acid and acetic acid, the mixture was stirred for 16 hours by a magnetic shaker. After adding ninhydrin reagents to each sample, $5 \mathrm{~mL}$ of glacial acetic acid was added again. The mixture was thoroughly stirred and put into the boiling water bath for 45 minutes at $100{ }^{\circ} \mathrm{C}$. After cooling, benzene was added to each sample and the samples were shaken vigorously, and then they were allowed to settle for 30 minutes to prevent proline from entering benzene phase. The top phase that contains benzene and proline is separated and its absorption intensity was measured using a spectrophotometer at $515 \mathrm{~nm}$ wavelength (Chorfi and Taibi, 2011).

\section{Measuring Carbohydrate Content}

To measure the dissolved carbohydrate, an extraction similar to that of proline was performed. After extraction, $0.1 \mathrm{~mL}$ of alcoholic extract was mixed with $3 \mathrm{~mL}$ of freshly prepared anthrone (150 mg anthrone $+100 \mathrm{~mL}$ of $72 \%$ sulfuric acid). The solution was then placed in a boiling water bath for ten minutes to react and become colored. The absorption rate was then measured using a spectrophotometer at $625 \mathrm{~nm}$ wavelength, and the sugar content was calculated (Ghobadi et al., 2011).

\section{Plant Extraction for Catalase Activity Assay}

$0.5 \mathrm{~g}$ of fresh leaf tissue, $3 \mathrm{~mL}$ of extraction buffer, $50 \mathrm{mM}$ Tris- $\mathrm{HCl}(\mathrm{pH}=7)$, containing $3 \mathrm{mM} \mathrm{MgCl}$, and $1 \mathrm{mM}$ EDTA were pulverized in a cooled mortar. The resulting homogenate was centrifuged at $5,000 \mathrm{rpm}$ for $20 \mathrm{~min}$ at $4^{\circ} \mathrm{C}$, using a refrigerated centrifuge of model 'Vision VS-15000 CFN'. The supernatant was then used to measure the activities of catalase and peroxidase (Wu, 2011).

\section{Guaiacol Peroxidase Enzyme Activity Assay (GPX, EC 1.11.1.7)}

To measure Guaiacol peroxidase (GPX) activity, the reaction mixture is $2.5 \mathrm{~mL}$ of $50 \mathrm{mM}$ phosphate buffer $(\mathrm{pH}=7)$ containing $1 \mathrm{~mL}$ of $1 \%$ guaiacol, $1 \mathrm{~mL}$ of $1 \% \mathrm{H}_{2} \mathrm{O}_{2}$ and $0.1 \mathrm{~mL}$ of the extract. GPX activity based on the rate of absorption increase per minute was calculated using a spectrophotometer (model UV / VIS Lambda25) set at $420 \mathrm{~nm}$ wavelength. To assay the activity, the Equation 3 and the extinction coefficient $\left(26 / 6 \mathrm{mM}^{-1} \mathrm{~cm}^{-1}\right)$ were used. 
Units $(\mathrm{Mm} / \mathrm{min})=\frac{\frac{\mathrm{doD}}{\min (\text { slop })} * \text { Vol. of assay }{ }^{*}(0.0001)}{\text { Extinction } \operatorname{cofficient}^{*}(26.6)}$

Where, extinction coefficient is $26.6 \mathrm{mM}^{-1} \mathrm{~cm}^{-1}$, doD is the difference between the highest and lowest numbers, and vol. of the assay is the absorption time during the test.

\section{Catalase enzyme activity assay (CAT, EC 1.11.1.6)}

The reaction mixture is $2.5 \mathrm{~mL}$ of $50 \mathrm{mM}$ phosphate buffer ( $\mathrm{pH}=7$ ) containing $0.2 \mathrm{~mL}$ of $1 \% \mathrm{H}_{2} \mathrm{O}_{2}$ and $0.3 \mathrm{~mL}$ of the extract. Catalase (CAT) activity based on the rate of absorption decrease per minute was calculated using a spectrophotometer (model UV / VIS Lambda25) set at $240 \mathrm{~nm}$ wavelength. To assay, the activity, the following formula and the extinction coefficient $\left(0.0436 \mathrm{mM}^{-1} \mathrm{~cm}^{-}\right.$ $\left.{ }^{1}\right)$ were used.

Units $(\mathrm{Mm} / \mathrm{min})=\frac{\frac{\mathrm{doD}}{\min (\text { slop })} * \text { Vol. of assay }(0.0003)}{\text { Extinction cofficient }(0.0436)}$

Before starting the statistical analysis, the data was tested for normality; then, the statistical analysis was performed using SAS. LSD and Duncan's tests at a $5 \%$ probability level were used to compare means. The required figures were created using Microsoft Excel software.

\section{Results and Discussion}

The results showed that the effects of the different dehydration levels, cultivar types and application of $*$
Mycorrhiza $*$ on proline of corn were significant at $5 \%$ level. Significant differences were observed between the effects of dehydration and cultivar type on stem dry weight and chlorophyll b content at a $1 \%$ statistical level. Similarly, they were also significant for catalase content and grain yield at a $5 \%$ level. The two effects of Mycorrhiza application and cultivar type on the number of stomata below the leaf area were significant at $1 \%$. The combined impact of Mycorrhiza application and dehydration on the number of stomata at the leaf surface was also significant at a $5 \%$ probability level (Table 2).

\section{Shoot Dry Weight}

In this study, the highest shoot dry weight (139.5 g) was obtained for cultivar 640 when irrigation after $70 \mathrm{~mm}$ evaporation from pan was applied. The lowest weight $(88.1 \mathrm{~g}$ ) was obtained from using irrigation after $150 \mathrm{~mm}$ evaporation from pan for cultivar 704 (Table 3). In general, susceptibility to water deficiency varied among cultivars, evident in their shoot dry weight. Cultivar 640 was more susceptible to water deficiency in terms of shoot dry weight than cultivar 704 (Table 4). Madani et al. (2010) reported that limited availability of resources like water would result in resource restrictions such as reducing the current photosynthesis rate; therefore, the dry matter accumulation in various plant parts decreases. Anjum et al (2011) stated that multiple mechanisms of root growth could be enhanced by the application of mycorrhiza. Studies show that mycorrhizal

Table 2. Analysis of variance for the characteristics of corn

\begin{tabular}{|c|c|c|c|c|c|c|c|}
\hline Source of variance & Df & $\begin{array}{l}\text { Shoot dry } \\
\text { weight }\end{array}$ & $\begin{array}{l}\text { The number of } \\
\text { stomata on the } \\
\text { lower surface } \\
\text { of leaves }\end{array}$ & $\begin{array}{l}\text { The number of } \\
\text { stomata on the } \\
\text { upper surface } \\
\text { of the leaves }\end{array}$ & $\begin{array}{l}\text { Chlorophyll } \\
\text { b content }\end{array}$ & $\begin{array}{l}\text { Carbohydrate } \\
\text { content }\end{array}$ & $\begin{array}{l}\text { Protein } \\
\text { content }\end{array}$ \\
\hline Replication & 2 & $507.194^{\mathrm{ns}}$ & $35.361^{\mathrm{ns}}$ & 3.444 ns & $1.734^{\text {ns }}$ & $2.333^{\text {ns }}$ & $1.028^{\mathrm{ns}}$ \\
\hline Water deficiency & 2 & $5009.694^{*}$ & 298.778 ns & $144.444 * *$ & $15.170^{*}$ & $120.583 *$ & $68.528^{*}$ \\
\hline main error & 4 & 463.611 & 54.403 & 6.528 & 1.007 & 7.792 & 4.444 \\
\hline Mycorrhiza & 1 & $992.250^{* *}$ & $28.444^{\mathrm{ns}}$ & $72.250 * *$ & $0.234^{\mathrm{ns}}$ & $156.250 * *$ & $28.444 * *$ \\
\hline Water deficiency*Mycorrhiza & 2 & $36.75^{\text {ns }}$ & $32.704^{\text {ns }}$ & 19.000* & $0.289^{\text {ns }}$ & $33.083^{\text {ns }}$ & $0.861^{\mathrm{ns}}$ \\
\hline Cultivar & 1 & $140.028^{\mathrm{ns}}$ & 5.444 ns & $0.028^{\text {ns }}$ & $1.247^{\text {ns }}$ & $1.361^{\text {ns }}$ & $0.444^{\mathrm{ns}}$ \\
\hline Water deficiency*cultivar & 2 & $675.694^{* *}$ & 3.444 ns & $5.444^{\text {ns }}$ & $3.217^{* *}$ & $4.528^{\text {ns }}$ & $0.861^{\mathrm{ns}}$ \\
\hline Mycorrhiza*cultivar & 1 & $318.028^{\text {ns }}$ & $196.000 * *$ & $3.361^{\text {ns }}$ & $0.047^{\text {ns }}$ & $4.694^{\text {ns }}$ & $4^{\text {ns }}$ \\
\hline $\begin{array}{l}\text { Water deficiency } \\
\text { *Mycorrhiza*cultivar }\end{array}$ & 2 & $201.194^{\text {ns }}$ & $16.333^{\mathrm{ns}}$ & $10.704^{\text {ns }}$ & $1.742^{\mathrm{ns}}$ & $9.028^{\text {ns }}$ & $1.083^{\mathrm{ns}}$ \\
\hline Secondary error & 18 & 78.509 & 16.019 & 4.278 & 0.517 & 13.454 & 2.972 \\
\hline $\begin{array}{l}\text { The coefficient of Variance } \\
\text { (percent) }\end{array}$ & & 7.84 & 9.75 & 8.17 & 12.58 & 4.82 & 20.15 \\
\hline
\end{tabular}


Continue Table 2. Analysis of variance for the corn characteristics

\begin{tabular}{|c|c|c|c|c|c|c|c|}
\hline Source of variance & Df & $\begin{array}{l}\text { Malondialdehyde } \\
\text { content }\end{array}$ & $\begin{array}{l}\text { The amount } \\
\text { of catalase }\end{array}$ & Peroxidase & Proline & $\begin{array}{l}\text { 100-kernel } \\
\text { weight }\end{array}$ & Grain yield \\
\hline Replication & 2 & $1.194^{\mathrm{ns}}$ & $9.194^{\mathrm{ns}}$ & $7.694^{\mathrm{ns}}$ & $0.394^{\mathrm{ns}}$ & $1.861^{\mathrm{ns}}$ & $93.361^{\mathrm{ns}}$ \\
\hline Water deficiency & 2 & $99.528^{*}$ & $152.861 * *$ & $330.361^{* *}$ & $2.787^{\mathrm{ns}}$ & $54.361^{*}$ & $8229.861^{* *}$ \\
\hline main error & 4 & 12.028 & 4.319 & 16.444 & 0.51 & 6.903 & 93.704 \\
\hline Mycorrhiza & 1 & $58.778^{\mathrm{ns}}$ & $160.444 * *$ & $400.000 *$ & $0.704^{\text {ns }}$ & $21.778^{* *}$ & $5353.361^{* *}$ \\
\hline Water deficiency* Mycorrhiza & 2 & $13.194 \mathrm{~ns}$ & $5.361^{\mathrm{ns}}$ & $0.083^{n s}$ & $0.22^{\mathrm{ns}}$ & $1.361^{\mathrm{ns}}$ & $143.028^{\text {ns }}$ \\
\hline Cultivar & 1 & $9^{\text {ns }}$ & $0.704^{\mathrm{ns}}$ & $121^{\mathrm{ns}}$ & $0.704^{n s}$ & $13.444^{*}$ & $2320.028^{*}$ \\
\hline Water deficiency* cultivar & 2 & $4.083^{\mathrm{ns}}$ & $37.194 *$ & $108.583^{\mathrm{ns}}$ & $0.344^{\mathrm{ns}}$ & $2.528^{\mathrm{ns}}$ & $2163.361^{*}$ \\
\hline Mycorrhiza* cultivar & 1 & $5.4444^{\mathrm{ns}}$ & $16^{\mathrm{ns}}$ & $49^{\text {ns }}$ & $0.028^{n s}$ & $0.444^{\mathrm{ns}}$ & $84.028^{\text {ns }}$ \\
\hline $\begin{array}{l}\text { Water deficiency* Mycorrhiza* } \\
\text { cultivar }\end{array}$ & 2 & $35.194^{\mathrm{ns}}$ & $7.583^{\mathrm{ns}}$ & $15.083^{\mathrm{ns}}$ & $1.047^{*}$ & $0.861^{\mathrm{ns}}$ & $1011.861^{\text {ns }}$ \\
\hline Secondary error & 18 & 20.269 & 7.537 & 51.639 & 0.18 & 2.407 & 428.157 \\
\hline $\begin{array}{l}\text { The coefficient of Variance } \\
\text { (percent) }\end{array}$ & & 17.06 & 12.51 & 20.21 & 10.53 & 6.63 & 18.93 \\
\hline
\end{tabular}

** and $*$ denote significance at probability level of five percent.

fungi increase root length, the number of roots and root thickness (Anjum et al., 2011). Similarly, Parniske (2008) also reported that the application of mycorrhizal fertilizers increases root number and root length in corn plants.

\section{The Number of Stomata on The Lower Surface of Leaves}

The highest number of stomata on the lower surface of the leaf was obtained with the application of mycorrhiza fertilizer and in cultivar 640. Application of mycorrhiza fertilizer caused a 15.7 percent increase in the number of stomata in the leaves of this cultivar (Table 4). Various studies have reported the effect of an increase in the number of mycorrhiza fungi on the stomata of plants. Abdallah et al. (2013) investigated the impact of mycorrhiza fungi on physiological characteristics of sunflowers and found that the use of mycorrhiza bio-fertilizer increases the number of stomata on the leaf surface in sunflower.

\section{The Number of Stomata on The Upper Surface of The Leaves}

The highest number of stomata on the upper surface of the leaves with a number of 30.8 was achieved at the irrigation treatment after $70 \mathrm{~mm}$ evaporation and mycorrhiza application. Whereas the lowest number with 22.6 was reached at irrigation after $150 \mathrm{~mm}$

Table 3. Interactive effects of irrigation and cultivars on study traits

\begin{tabular}{cccccc}
\hline $\begin{array}{c}\text { Irrigation surfaces } \\
\text { (mm evaporation) }\end{array}$ & Cultivar & $\begin{array}{c}\text { Dry weight per } \\
\text { shoot }(\mathrm{g})\end{array}$ & $\begin{array}{c}\mathrm{B} \text { (mg per g on the } \\
\text { wet weight) }\end{array}$ & $\begin{array}{c}\text { The amount of } \\
\text { catalase (absorption } \\
\text { per mg protein) }\end{array}$ & $\begin{array}{c}\text { Grain yield per } \\
\text { unit area (g) }\end{array}$ \\
\hline 70 & 704 & $120.8^{\mathrm{bc}}$ & $6.100^{\mathrm{b}}$ & $17.67^{\mathrm{c}}$ & $152.8^{\mathrm{a}}$ \\
70 & 640 & $139.5^{\mathrm{a}}$ & $7.467^{\mathrm{a}}$ & $18.00^{\mathrm{c}}$ & $108.0^{\mathrm{bc}}$ \\
110 & 704 & $124.2^{\mathrm{b}}$ & $6.167^{\mathrm{b}}$ & $26.17^{\mathrm{a}}$ & $123.3^{\mathrm{b}}$ \\
110 & 640 & $112.8^{\mathrm{c}}$ & $5.467^{\mathrm{bc}}$ & $22.33^{\mathrm{b}}$ & $704.7^{\mathrm{b}}$ \\
150 & 704 & $88.17^{\mathrm{d}}$ & $4.317^{\mathrm{d}}$ & $22.17^{\mathrm{b}}$ & $75.83^{\mathrm{d}}$ \\
150 & 640 & $92.67^{\mathrm{d}}$ & $4.767^{\mathrm{cd}}$ & $25.33^{\mathrm{b}}$ & $84.17^{\mathrm{cd}}$ \\
\hline
\end{tabular}

Superscripts (a-d) show significant differences in each column $(p<0.05)$. 
Table 4. Interactive effects of mycorrhiza and cultivars on study traits

\begin{tabular}{ccc}
\hline Mycorrhiza & Cultivar & The number of stomata on the lower surface of leaves \\
\hline Non-applicable & 704 & $42.11^{\mathrm{ab}}$ \\
Non-applicable & 640 & $38.22^{\mathrm{b}}$ \\
Applicable & 704 & $39.22^{\mathrm{b}}$ \\
Applicable & 640 & $44.6^{\mathrm{a}}$ \\
\hline
\end{tabular}

Superscripts (a-b) show significant differences in each column $(p<0.05)$.

evaporation and when mycorrhiza was not applied. The application of mycorrhiza under complete irrigation conditions undoubtedly increases the number of stomata on corn leaves' surface. However, the increase in the number of stomata at the upper surface of the leaf and the sensitivity was higher in water shortage conditions. That can have a positive impact on the reduction of evaporation from the leaf surface (Table 5). The number of stomata in each plant is a genetic trait, but they usually interact with environmental and nutritional factors. Studies have shown that hormonal changes affect the number of stomata (Šantrůček et al., 2014). Likewise, some studies have reported that mycorrhiza fungi and phosphate fertilizer increased levels of the hormone in plants (Sivagurunathan, 2014).

\section{Chlorophyll b}

In this study, unlike the amount of chlorophyll a, chlorophyll b was not affected by mycorrhiza application; however, the irrigation levels and the cultivar had a significant impact on the content of chlorophyll b (Table 6). The comparison of chlorophyll b under the influence of irrigation levels and cultivar showed that the highest content of chlorophyll b was obtained in irrigation after $70 \mathrm{~mm}$ evaporation by cultivar 640 . Under full irrigation, cultivar 640, in comparison with 704 cultivars, showed more content of chlorophyll b, but under drought conditions, no significant difference was observed in chlorophyll b content (Table 3). Robinson et al. (2014) also showed a significant increase of chlorophyll $b$ in sesame plants using mycorrhiza bio-fertilizer. Despite the fact that under the irrigation condition, there was more amount of chlorophyll b in cultivar 640 compared to cultivar 704, cultivar 640 , however, showed a higher sensibility to drought when compared to cultivar 704 . Both levels of water shortage irrigation after 110 and $150 \mathrm{~mm}$ evaporation caused a significant reduction of 27 and 36.4 percent in the content of chlorophyll $b$ in cultivar 640 . However, in cultivar 704, water shortage after irrigation of $150 \mathrm{~mm}$ evaporation was the only one with a significant chlorophyll b reduction (29.5 \%).

\section{Carbohydrate Content}

The present study showed that carbohydrate content was affected by irrigation after 110 and 150 $\mathrm{mm}$ evaporation. A decrease of 5 and 8 percent, respectively, was observed (Table 6 ). Initially, during the grain filling stage, the primary compounds stored in the grain are protein and then later, carbohydrate compounds become stored in the grain as well. Therefore, since grain filling will be shortened due to the water deficit, accumulated carbohydrate percentage will be lower while protein percentage will be higher (Ghobadi et al., 2011). Similarly, Ghobadi et al. (2011) found a significant reduction in carbohydrate content of grains under the effect of water shortage. In this study,

Table 5. Interactive effects of mycorrhiza and irrigation on study traits

\begin{tabular}{ccc}
\hline $\begin{array}{c}\text { Irrigation surfaces (mm } \\
\text { evaporation) }\end{array}$ & Mycorrhizal & $\begin{array}{c}\text { The number of stomata on the leaf } \\
\text { surface }\end{array}$ \\
\hline 70 & Non-applicable & $25.33^{\mathrm{b}}$ \\
70 & Applicable & $30.83^{\mathrm{a}}$ \\
110 & Non-applicable & $26.17^{\mathrm{b}}$ \\
110 & Applicable & $26.67^{\mathrm{b}}$ \\
150 & Non-applicable & $20.17^{\mathrm{d}}$ \\
150 & Applicable & $22.67^{\mathrm{c}}$ \\
\hline
\end{tabular}

Superscripts (a-d) show significant differences in each column $(p<0.05)$. 
Table 6. Effects of irrigation on study traits

\begin{tabular}{cccccc}
\hline $\begin{array}{c}\text { Irrigation surface } \\
\text { (evaporation mm) }\end{array}$ & $\begin{array}{c}\text { Carbohydrate } \\
\text { content (\%) }\end{array}$ & $\begin{array}{c}\text { Protein } \\
\text { content (\%) }\end{array}$ & Malondialdehyde & $\begin{array}{c}\text { Peroxidase } \\
\text { (absorbed per mg } \\
\text { protein) }\end{array}$ & $\begin{array}{c}\text { Hundredweight } \\
(\mathrm{g})\end{array}$ \\
\hline 70 & $79.33^{\mathrm{a}}$ & $6.333^{\mathrm{b}}$ & $23.42^{\mathrm{b}}$ & $29.50^{\mathrm{b}}$ & $25.08^{\mathrm{a}}$ \\
110 & $75.92^{\mathrm{b}}$ & $8.250^{\mathrm{b}}$ & $26.58^{\mathrm{ab}}$ & $38.42^{\mathrm{a}}$ & $24.08^{\mathrm{a}}$ \\
150 & $73.00^{\mathrm{b}}$ & $11.08^{\mathrm{a}}$ & $29.17^{\mathrm{a}}$ & $38.75^{\mathrm{a}}$ & $21.00^{\mathrm{b}}$ \\
\hline
\end{tabular}

Superscripts (a-c) show significant differences in each column $(p<0.05)$.

the application of mycorrhiza significantly increased the carbohydrate content of corn.

\section{Protein Content}

By reducing the amount of irrigation water from irrigation after $70 \mathrm{~mm}$ evaporation to after $150 \mathrm{~mm}$ evaporation, the protein content increased up to 74.7 percent (Table 6). An inverse relationship between the amount of carbohydrates and the amount of protein in the grain is observed; that is, the amount of protein reduces as that of carbohydrates increases. Ghobadi et al. (2011) showed that the protein content of corn grain increases as the tension percent increases. So, the least amount of protein was obtained under full irrigation, and the highest amount of protein was obtained under severe drought tension. However, the percentage of protein content in grain under mild and severe moisture stress conditions did not show any significant difference. Water shortage tension does not decrease the remobilization of nitrogen from leaves to grains, increasing the protein content of the grain. The application of mycorrhiza had a significant effect on the protein content of corn grains. The protein content when mycorrhiza was applied is 9.4 percent, while under no-application, the protein content is $22 \%$ more.

\section{Malondialdehyde Content}

In this study, reduction in the water available from irrigation after $70 \mathrm{~mm}$ evaporation to irrigation after 150 $\mathrm{mm}$ evaporation resulted in $24.3 \%$ malondialdehyde (Table 6). Valentovic et al. (2006), in a study on corn, observed that water shortage leads to the increase of electrolyte leakage because the cell membrane stability decreases. Water shortage increases the production of active forms of oxygen, allowing the cell membranes to be attacked and thus generating malondialdehyde. The amount of malondialdehyde is an index of membrane damage. Anjum et al (2011) stated that the damage to cell membranes causes an increase in electrolyte leakage rate.

\section{Catalase Content}

According to the results of this study, the highest amount of catalase in irrigation treatment was obtained after $110 \mathrm{~mm}$ evaporation and cultivar 704 . The lowest levels were obtained in irrigation after 70 $\mathrm{mm}$ evaporation and in both cultivars 704 and 640 . For cultivar 704, both irrigation treatments after 110 and $150 \mathrm{~mm}$ evaporation caused a 48.2 and 25.5 percent increase in the catalase content of corn leaves, respectively. Similarly, for cultivar 640 , both irrigation treatments after 110 and $150 \mathrm{~mm}$ evaporation caused a respective 23.8 and $40.5 \%$ increase in the catalase of corn leaves (Table 3). Moussa and Abdel-Aziz (2008) showed that water shortage could cause an increase the amount of antioxidants in corns. In this study, the application of mycorrhiza had a significant increase in the catalase content of corn leaves. In a similar study, Wu (2011) also showed that the use of mycorrhiza significantly increased the catalase content.

\section{Peroxidase}

It was observed that water shortage caused a significant increase in the peroxidase content of corn leaves. Both irrigations after 110 and $150 \mathrm{~mm}$ evaporation significantly increased the peroxidase content of corn leaf by $31 \%$. No significant difference was observed in peroxidase content between irrigation treatments after 110 and $150 \mathrm{~mm}$ evaporation (Table 6). Li-Ping et al. (2006) observed similar results in corn, he noted an increase in peroxidase content in leaves of corn due to the water shortage impact. Wu (2011) also showed that the use of mycorrhiza significantly increased the peroxidase content of corn leaves.

\section{Proline Content}

The highest content of proline in irrigation treatment was achieved after $110 \mathrm{~mm}$ evaporation and the application of mycorrhiza in cultivar 704. The lowest Proline content was also related to irrigation after 70 $\mathrm{mm}$ evaporation and no-application of mycorrhiza in cultivar 640 . According to the results, in irrigation after 
Table 7. Comparison of the averages of the traits affected by irrigation surfaces and mycorrhizal application in corn cultivars

\begin{tabular}{cccc}
\hline $\begin{array}{c}\text { Irrigation surfaces } \\
\text { (mm evaporation) }\end{array}$ & Mycorrhizal treatment & Cultivar & Proline \\
\hline 70 & Non-applicable & 704 & $3.467^{\mathrm{cd}}$ \\
70 & Non-applicable & 640 & $3.167^{\mathrm{d}}$ \\
70 & Applicable & 704 & $3.467^{\mathrm{cd}}$ \\
70 & Applicable & 640 & $3.867^{\mathrm{b}-\mathrm{d}}$ \\
110 & Non-applicable & 704 & $3.967^{\mathrm{b}-\mathrm{d}}$ \\
110 & Non-applicable & 640 & $4.200^{\mathrm{a}-\mathrm{c}}$ \\
110 & Applicable & 704 & $4.867^{\mathrm{a}}$ \\
110 & Applicable & 640 & $3.633^{\mathrm{cd}}$ \\
150 & Non-applicable & 704 & $4.567^{\mathrm{ab}}$ \\
150 & Non-applicable & 640 & $4.467^{\mathrm{ab}}$ \\
150 & Applicable & 704 & $4.167^{\mathrm{a}-\mathrm{c}}$ \\
150 & Applicable & 640 & $4.500^{\mathrm{ab}}$ \\
\hline
\end{tabular}

Superscripts (a-d) show significant differences in each column $(p<0.05)$.

$110 \mathrm{~mm}$ evaporation and cultivar 704, the application of mycorrhiza caused a significant increase of $23 \%$ in the proline content of the leaves of corn. However, for other irrigation levels, mycorrhiza had no significant impact on the proline content of corn leaves. Also, in a condition of no-application of mycorrhiza, irrigation after 150 mm evaporation of both cultivars 704 and 640 resulted in a respective 32.3 and $41.9 \%$ reduction in proline content of corn leaves (Table 7). Studies have shown that proline increases under water shortage conditions, which plays an important role in osmotic adjustment (Chorfi and Taibi, 2011).

\section{0-kernel Weight}

According to this study's findings, irrigation after $150 \mathrm{~mm}$ of evaporation from the evaporation pan resulted in a $16 \%$ loss of the 100-kernel weight of corn compared with that of irrigation after $70 \mathrm{~mm}$ of evaporation from the evaporation pan (Table 6). Kernel weight in plants is decided by two factors: the kernel filling rate and the duration of kernel filling. Water deficiency negatively affects both factors that determine the kernel weight. Water deficiency reduces the kernel filling rate by increasing the viscosity of phloem sap and reducing the rate of photosynthesis. It also reduces the filling duration, as reported by Lisanti et al (2013). Khoshvaghti et al. (2014) observed a 27 $\%$ loss of 100-kernel weight of corn after imposing water deficiency. Significant differences were observed between the cultivars in terms of the kernel weight. Farnia and Khodabandeloo (2015) reported that the application of mycorrhiza leads to a significant increase in the kernel number of corn. In the case of a limited number of assimilates, increasing the number of kernels leads to the reduction of assimilate supply per kernel, resulting in kernel weight reduction (Krupnova, 2010).

\section{Grain Yield}

The highest corn grain yield per unit area was obtained in irrigation after $70 \mathrm{~mm}$ evaporation in cultivar 704, and the least was obtained in irrigation after $150 \mathrm{~mm}$ evaporation in cultivar 704 likewise. When the irrigation levels was decreased from after $70 \mathrm{~mm}$ evaporation to irrigation after $150 \mathrm{~mm}$ evaporation, cultivar 704's grain yield decreased severely when comparison with yield in irrigation after $110 \mathrm{~mm}$ evaporation. Furthermore, cultivar 640 had a lower yield compared to the 704 cultivars under the specific conditions of irrigation after $70 \mathrm{~mm}$ evaporation. No significant difference was observed in grain yield under conditions of irrigation after $70 \mathrm{~mm}$ evaporation and irrigation after $150 \mathrm{~mm}$ evaporation. However, under irrigation after $150 \mathrm{~mm}$ evaporation, corn grain yield in cultivar 640 was $64.3 \%$ lesser when compared with irrigation after $110 \mathrm{~mm}$ evaporation. In general, it was observed that under a full irrigation system, the grain yield of cultivar 640 in comparison with 704 was $28.9 \%$ lower. Similarly, in drought conditions, there was no significant difference in 
grain yield between the cultivars (Table 3). Mohammadai et al. (2012) studied the effect of irrigation on corn and reported that with decreasing levels of irrigation from after $130 \mathrm{~mm}$ evaporation to after $70 \mathrm{~mm}$ evaporation, corn grain weight decreased by $54 \%$. Khoshvaghti et al. (2014), in a study of the impact of water shortage on corn, also found out that the decrease of water in irrigation from after $50 \mathrm{~mm}$ evaporation to after $90 \mathrm{~mm}$ evaporation caused a $25.8 \%$ reduction in the corn grain weight. Water shortage in the flowering stage reduces the number of grains; the significant reasons behind this are the decrease of assimilates for corn growth and increase in the floret sterility (Anjum et al., 2011). In other similar studies, Farnia and Khodabandehloo (2015) also obtained a significant increase in corn grain yield as a result of mycorrhiza fertilizers application.

\section{CONCLUSION}

According to the results, it can be stated that all three factors of water deficiency, mycorrhiza application and cultivar caused a significant change in grain yield by changing both the main components of grain number and the hundred-kernel weight. All three factors of water deficiency, mycorrhiza application and cultivars could therefore be related to grain yield number and 100-kernel weight. Due to the lack of significant differences between yield in cultivars under water deficient conditions and results showing that cultivar 704 produces the highest yield, planting cultivar 704 and Mycorrhizal treatment is therefore recommended in the studied area.

\section{ACKNOWLEDGMENTS}

We thank the Faculty of Agriculture, Malekan Branch, Islamic Azad University, Malekan, Iran for funding this research.

\section{CONFLICT OF INTEREST}

The author states that this article is original research that has not been published in another Journal and that there is no conflict of interest.

\section{REFERENCES}

Abdallah, M. M.,Abd El-Monem, A. A.,Hassanein, R. A., \& ElBassiouny, H. M. S. (2013). Response of sunflower plant to the application of certain vitamins and arbuscular mycorrhiza under different water regimes. Australian Journal of Basic Applied Science, 7(2): 915-932.
Afshar, R. K., Jovini, M. A., Chaichi, M. R., \& Hashemi, M. (2014). Grain sorghum response to arbuscular mycorrhiza and phosphorus fertilizer under deficit irrigation. Agronomy Journal, 106(4): 1212-1218. http://doi.org/10.2134/ agronj13.0589

Anjum, S.A., Xie, X.Y., Wang, L.C., Saleem, M.F., Man, C., \& Lei, W. (2011). Morphological, physiological and biochemical responses of plants to drought stress. African Journal of Agricultural Research, 6(9): 20262032. http://doi.org/10.5897/AJAR10.027

Chen, X., Song, F., Liu, F., Tian, C., Liu, S., Xu, H., \&Zhu, X. (2014). Effect of different arbuscular mycorrhizal fungi on growth and physiology of maize at ambient and low temperature regimes. Hindawi Publishing Corporation,5: 1-8. http://doi.org/10.1155/2014/956141

Chorfi, A., \& Taıbi, K. (2011). Biochemical screening for osmotic adjustment of wheat genotypes under drought stress. Tropiculture, 29(2): 82-87.

Dadrasan, M., Chaichi, M. R., Pourbabaee, A. A., Yazdani, D., \& Keshavarz-Afshar, R. (2015). Deficit irrigation and biological fertilizer influence on yield and trigonelline production of fenugreek. Industrial Crops Production, 77: 156-162. http://doi.org/10.1016/j.indcrop.2015.08.040

Farnia, A., \& Khodabandehloo, S. (2015). Changes in yield and its components of maize (Zea mays L.) to foliar application of Zinc nutrient and mycorrhiza under water stress condition. International Journal of Life Science, 9(5): 75-80. http://doi.org/10.3126/ijls.v9i5.12702

Ghobadi, R. P., Shirkhani, S., \&Fattahi, K. (2011). Studying the effects of drought stress and nitrogen fertilizer on relative water content of leaf, percentage of carbohydrates, protein, fat and cross grain hectoliter weight of corn single cross 704. The first national conference on new issues in agriculture. Saveh Islamic Azad University.

Jahanzad, E., Jorat, M., Moghadam, H., Sadeghpour, A., Chaichi, M. R., \& Dashtaki, M. (2013). Response of a new and a commonly grown forage sorghum cultivar to limited irrigation and planting density. Agricultral Water Management, 117:62-69. http://doi.org/10.1016/j. agwat.2012.11.001

Khalil, S. E., \& El-Noemani, A. S. A. (2015). Effect of bio-fertilizers on growth, yield, water relations, photosynthetic pigments and carbohydrates contents of (Origanum vulgare L.) plants grown under water stress conditions. American Eurasian Journal of Sustainable Agriculture, 9(4): 60-73.

Khoshvaghti, H., Eskandari-Kordlar, M., \&Lotfi, R. (2014). Response of maize cultivars to water stress at grain filling phase. Azarian Journal of Agriculture,1(1): 39-42.

Krupnova, O. V. (2010). Relation between grain weight and falling number in soft spring wheat. Russian Agriculture 
Science 36(5): 321-323. http://doi.org/10.3103/ S1068367410050010

Li-Ping, B. A. I., Fang-Gong, S. U. I., Ti-Da, G. E., Zhao-Hui, S. U. N., Yin-Yan, L. U., \& Guang-Sheng, Z. H. O. U. (2006). Effect of soil drought stress on leaf water status, membrane permeability and enzymatic antioxidant system of maize. Pedosphere, 16(3): 326-332. http:// doi.org/10.1016/S1002-0160(06)60059-3

Lisanti, S., Hall, A. J., \& Chimenti, C. A. (2013). Influence of water deficit and canopy senescence pattern on (Helianthus annuus L.) root functionality during the grain-filling phase. Field Crops Research, 154: 1-11. http://doi.org/10.1016/j.fcr.2013.08.009

Maazou, A. R. S., Tu, J., Qiu, J., \& Liu, Z. (2016). Breeding for drought tolerance in maize (Zea mays L.). American Journal of Plant Sciences, 7(14): 48-58. http://doi. org/10.4236/ajps.2016.714172

Madani, A., Shirani-Rad, A., Pazoki, A., Nourmohammadi, G., Zarghami, R., \& Mokhtassi-Bidgoli, A. (2010). The impact of source or sink limitations on yield formation of winter wheat (Triticum aestivum L.) due to post-anthesis water and nitrogen deficiencies. Plant, Soil \& Environment, 56(5): 218-227. http://doi.org/10.17221/217/2009-PSE

Mirzaei, A., Naseri, R., Soleymanifard, A., \& Vazan, S. (2011). Effect of plant growth promoting rhizobacteria (PGPR) on agronomic characteristic and root colonization in fennel. Plant Medical, 77(12):5. http://doi. org/10.1055/s-0031-1282259

Mohammadai, H., \& Shams, A. S. (2012). Evaluation of drought stress effects on yield components and seed yield of three maize cultivars (Zea mays L.) in Isfahan region. International Journal of Agriculture and Crop Science, 4(19): 1436-1439.

Moussa, H. R., \&Abdel-Aziz, S. M. (2008). Comparative response of drought tolerant and drought sensitive maize genotypes to water stress. Australian ournal of Crop Science,1(1): 31-36.
Nyaga, J., Muthuri, C. W., Matiru, V. N., Jefwa, J. M., Okoth, S. A., \& Wachira, P. (2014). Influence of soil fertility amendment practices on ex-situ utilization of indigenous arbuscular mycorrhizal fungi and performance of maize and common bean in Kenyan highlands. Tropical and Subtropical Agroecosystems, 17(1): 129-141.

Oskuie, P. A., \& Cirus, S. B. (2015). The effect of vesiculararbuscular (VA) mycorrhizal fungi on vitamin $C$ content of tomato in the presence of lead and different levels of phosphorus. Bulletin of Environment, Pharmacology and Life Sciences, 4: 01-04.

Parniske, M. (2008). Arbuscular mycorrhiza: the mother of plant root endosymbioses. Nature Reviews Microbiology, 6(10): 763. http://doi.org/10.1038/nrmicro1987

Robinson, J. P., Nithya, K., Ramya, R., Karthikbalan, B., \& Kripa, K. (2014). Effect of vesicular arbuscular mycorrhiza Glomus fasciculatum on the growth and physiological response in (Sesamum indicum L.) International Letters of Natural Sciences, 23: 47-62. http://doi.org/10.18052/ www.scipress.com/ILNS.23.47

Šantrưček, J., Vráblová, M., Šimková, M., Hronková, M., Drtinová, M., Květoň, J., \& Neuwithová, J. (2014). Stomatal and pavement cell density linked to leaf internal $\mathrm{CO}_{2}$ concentration. Annual Botany, 114(2): 191202. http://doi.org/10.1093/aob/mcu095

Sivagurunathan, P., Sathiyamoorthy, M., \&Sivasubramani, K. (2014). Effect of mycorrhizal fungi on growth of (Zea mays L.) plants. International Journal of Advanced Research in Biological Science, 1(1): 137-148.

Valentovic, P., Luxova, M., Kolarovic, L., \& Gasparikova, O. (2006). Effect of osmotic stress on compatible solutes content, membrane stability and water relations in two maize cultivars. Plant, Soil \& Environment, 52(4): 184.

Wu, Q. S. (2011). Mycorrhizal efficacy of trifoliate orange seedlings on alleviating temperature stress. Plant, Soil \& Environment, 57(10): 459-464. http://doi. org/10.17221/59/2011-PSE 